\title{
ПРОФЕСІЙНА МАЙСТЕРНІСТЬ МАЙБУТНЬОГО ФАХІВЦЯ МУЗИЧНОГО МИСТЕЦТВА ЯК ФАКТОР РЕАЛІЗАЦІЇ НОВІТНЬОЇ ПАРАДИГМИ ОСВІТИ
}

conf. (St. Petersburg, May). (pp. 95-97.). Saint Petersburg. [in Russian].

10. Krok do tolerantnosti: vykorystannia arttekhnolohii u zakhysti prav ditei-bizhentsiv (2010).[A step towards tolerance: the use of art technologies in the protection of the rights of refugee children]. (Ed.). R. Bezpalcha and others. Kyiv, 24 p. [in Ukrainian].

11. Medvedeva, E., Levchenko, I., Komissarova, L., \& Dobrovolskaya, T. (2011). Artpedagogika i artterapiya v spetsialnom obrazovanii: ucheb. posob. [Art pedagogy and art therapy in special education: textbook. Allowance]. Moscow, 248 p. [in Russian].

12. Onyschuk, I. (2017). Rozvytok samovyrazhennia zrostaiuchoi osobystosti u muzychno-tvorchii diialnosti [Development of self-expression of a growing personality in musical and creative activities]. Aktualni problemy pedahohichnoi osvity: yevropeiskyi $i$ natsionalnyi vymir: materialy $I$
Mizhnarod. nauk.-prakt. konf. "Aktualni problemy pedahohichnoi osvity: yevropeiskyi $i$ natsionalnyi vymir" (Lutsk, 3-5 chervnia 2016 r.) - Actual problems of pedagogical education: European and national dimension: Proceedings of the I International Scientific-Practical Conference "Actual problems of pedagogical education: European and national dimension" June 3-5, 2016. (Eds.). P.M.Gusak, I.M. Brushnevskaya and others. Vol.2. (pp. 25-26). Lutsk. [in Ukrainian].

13. Prima, R. (2016). Artpedahohika yak naukove poniattia: aspekty sutnisnoi kharakterystyky [Art pedagogy as a scientific concept: aspects of the essential characteristics]. Bulletin of Cherkasy University. Series: pedagogical sciences. No. 1, pp. 6-10. [in Ukrainian].

14. Psykholohichnyi slovnyk (2007). [Psychological Dictionary]. (Eds.).V. Sinyavsky, O. Sergeenkova; for order. N. Pobirchenko. Kyiv, 274 p. [in Ukrainian].

Стаття надійшла до редакції 10.11.2020

УДК 378.147:[37.011.3-051:78]:005.336.5

DOI:

Марина Петренко, кандидат педагогічних наук, доцент кафедри хорового диригування, вокалу та методики музичного навчання Сумського державного педагогічного університету імені А. С. Макаренка

\section{ПРОФЕСІЙНА МАЙСТЕРНІСТЬ МАЙБУТНЬОГО ФАХІВЦЯ МУЗИЧНОГО МИСТЕЩТВА ЯК ФАКТОР РЕАЛІЗАЦЇ̈ НОВІТНЬОӤ ПАРАДИГМИ ОСВІТИ}

У статті розкрита професійна майстерність майбутнього фахівия музичного мистеитва як фактор реалізації новітньої парадигми освіти. Проаналізовано стан розробленості означеної проблеми в сучасних дослідженнях. Визначено зміст професійної майстерності майбутнього фахівия музичного мистеитвва. Окреслено певні завдання підвищення рівня професійної майстерності майбутнього учителя музики. Виявлено, щзо знання, вміння і навички, закладені впродовж навчально-виховного процесу в студентів позначаться на результатах підготовки майбутніх професійних кадрів, реалізачї̈ ӥх як особистостей новітньої парадигми освіти.

Ключові слова: професійна майстерність; майбутній фахівець музичного мистецтва; завчання; сучасна ocвima.

Jim. 6.

Maryna Petrenko, Ph.D.(Pedagogy), Associate Professor of the Choral Conducting, Vocal and Methods of Music Education Department Sumy A. S. Makarenko State Pedagogical University

\section{PROFESSIONAL SKILLS OF THE FUTURE MUSICAL ART SPECIALIST AS A FACTOR OF IMPLEMENTATION OF THE LATEST PARADIGM OF EDUCATION}

In the article it is highlighted the professional skills of the future musical art specialist as a factor of implementation of the latest education paradigm. According to the analysis of the state of this problem in modern researches, it is emphasized that the issue of future musical art specialist' professionalism involves greater perfection in terms of deepening knowledge, skills and creative use of scientific achievements and experience of prominent musical art representatives. This approach opens new opportunities for in-depth and high-quality teaching process. In this regard, it is highlighted the principle of systematicity and consistency, which creates the professional skills of a future musical art specialist.

The content of professional skills of the future musical art specialist is defined, which makes acquisition of necessary knowledge, abilities, and skills, spiritual values on the basis of mastering of musical pedagogics in 
particular, embodied in musical art samples, and also the use of new forms, methods and means in pedagogical activity.

The certain tasks of raising the professional skills level of the future music teacher are outlined, namely: 1) promotion the formation of knowledge, skills, abilities that provide the opportunity to implement professional music education; 2) possession of the instrument of future musical art teachers in the conditions of comprehensive school; 3) creating a comfortable learning environment for the future musical art specialists' professional activity.

It is revealed that the professional skills of the future musical art specialist are an important component of the professional competence of future musical art teachers. It is specified that the professional skills level of the future musical art specialist is an important condition for further development and improvement of domestic pedagogics. The knowledge, skills and abilities laid down for students during the educational process will affect the results of the future professionals' training, their realization as individuals of the latest paradigm of education.

Keywords: professional skills; future musical art specialist; tasks; modern education.

$\Pi$ остановка проблеми. Визначальну роль в ефективному впровадженні у мистецький освітній простір новітньої парадигми освіти XXI ст. відіграє прилучення української культури і мистецтва. I це потрібно для розвитку кожної особистості на засадах культурних цінностей українського суспільства, визначальною ознакою яких є прагнення осягнути сенс існування людини через залучення студентської молоді до культурно-творчого осмислення найкращих зразків музичного мистецтва.

Актуальність проблеми визначається сучасними високими вимогами до особистості вчителя музичного мистецтва, відповідно до Національної стратегії розвитку освіти України, рекомендацій Європейського парламенту та Ради Європи, ключової реформи "Нова українська школа”, що зумовлює необхідність перегляду змісту, форм, методів, створення необхідних умов для формування професійної готовності майбутніх спеціалістів, здатних організовувати різні види художньо-творчої діяльності та творчо самореалізовуватися в означеній діяльності.

Сучасні науковці наголошують, що одне 3 провідних місць у фаховій підготовці студентів закладів вищої освіти мистецького спрямування належить музичній освіті як найбільш демократичної, доступної для широкого кола дітей і юнацтва формі активної творчої діяльності. Тож, особливої уваги у контексті ствердження реалізації новітньої парадигми освіти, на думку Т. Жигінас, потребує проблема становлення духовності особистості, розвитку іiї художньоестетичної та творчо-виконавської культури, здатності до повноцінного сприйняття творів високого мистецтва [2]. Тобто освітній потенціал музичного мистецтва уможливлює й актуалізує необхідність формування професійної майстерності майбутнього фахівця музичного мистецтва як компонента духовної культури людства.

Саме така ідея покладена в основу новітньої освітньої парадигми XXI ст., реалізація якої на грунті концепції духовності виховання, потребує кардинальної зміни акцентів щодо завдань вищої освіти у сучасному демократичному суспільстві, першорядним 3 яких стає розробка таких напрямків її розвитку, які мають здійснюватися в ім'я збереження ідентичності людини як особистості та суб'єкта освітнього середовища й мистецького зокрема.

Аналіз останніх досліджень і публікацій. Аналіз сучасних науково-методичних досліджень з означеної проблеми дав змогу встановити, що проблема професійної майстерності майбутнього фахівця музичного мистецтва досить глибоко досліджувана науковцями багатьох галузей наук.

У музичній педагогіці початку XXI ст. свої погляди у працях актуалізують щодо історії розвитку музично-педагогічної освіти Г. Ніколаї, Т. Танько, В. Черкасов та інші; фахової підготовки вчителя музики, удосконалення його педагогічної майстерності висвітлені у студіях І. Зязюна, Т. Люріної, В. Орлова, Г. Падалки, О. Рудницької, О. Ростовського та інших; розв'язанню питань 3 набуття музично-педагогічної освіти слугують фундаментальні дослідження: О. Комаровської, О. Михайличенко, О. Лобової, О. Олексюк, О. Отич, Я. Сверлюк, О. Хижної та ін. Водночас проблема професійної майстерності майбутнього фахівця музичного мистецтва у новому освітньому просторі України початку XXI не знайшла достатнього висвітлення у науковій навчально-методичній літературі.

Мета статті - проаналізувати професійну майстерність майбутнього фахівця музичного мистецтва в культурно-освітньому просторі початку XXI ст. Відповідно до поставленої мети, визначили такі завдання: 1) з'ясувати стан розробленості означеної проблеми в сучасних дослідженнях; 2) визначити зміст професійної майстерності майбутнього фахівця музичного мистецтва; 3) окреслити певні завдання підвищення рівня професійної майстерності майбутнього учителя музики.

Виклад основного матеріалу дослідження. Актуальними питаннями освітнього простору на початку XXI ст. залишаються: зорієнтованість 
навчання і виховання особистості, створення умов для самостійного навчання, культивування внутрішніх стимулів духовного розвитку, творчості, активності, шляхи особистості на самовиховання.

Доведено, що педагогічна майстерність - це сукупність якостей особистості, які забезпечують високий рівень самоорганізації професійної діяльності педагога. Складовими професійної майстерності є професійні знання, педагогічна техніка, педагогічні здібності, педагогічна моральність, професійно значущі якості, зовнішня культура. Крім того, педагогічна майстерність включає в себе і психолого-педагогічну ерудицію, і вміння у галузі педагогічної техніки, пов'язані 3 педагогічними здібностями педагога, його творчими можливостями.

Дуже важливими у наш час видаються питання педагогічних технологій, пов'язаних 3 поняттями професійної майстерності майбутнього фахівця музичного мистецтва. Можна бути професійно компетентним педагогом, вільно орієнтуватися у предметній сфері, системно сприйматися і діяти у педагогічній реальності, мати особистісно-гуманітарну орієнтацію, вміти узагальнювати та передавати свій досвід іншим колегам, бути здатним до рефлексії, але опанувати професійну майстерність майбутнього фахівця музичного мистецтва дуже складно. Щоб бути неповторним, досконалим майстром, необхідно мати глибокі всебічні знання і навички концептуального професійного мислення. Професійна майстерність майбутнього фахівця музичного мистецтва $\epsilon$ його особистим внеском у педагогічну культуру суспільства, і завдяки усвідомленню механізмів власної діяльності уможливлює передачу майстерності іншим. Тому у справжнього майстра з'являється авторська система, своя школа, свої послідовники.

Нагадаємо, що музичне мистецтво - це естетичне освоєння світу в процесі художньої творчості як особливого виду людської діяльності, що відображає дійсність у конкретно-чуттєвих образах відповідно до певних естетичних ідеалів. Музичне мистецтво виховує у людині не лише потребу художньої насолоди, а й здатність творчого ставлення до всіх природних і суспільних явищ. Тому завдяки особливостям музичного мистецтва впливу на людину музика є однією 3 найважливіших складових частин духовної культури, суспільства.

Професійна майстерність майбутнього фахівця музичного мистецтва є багатоаспектною. Вона охоплює наукові пошуки, суто викладацьку діяльність, методичну роботу, виховний та організаційний вплив на учнів, самовдосконалення. Реалізація всіх музичних видів професійної майстерності майбутнього фахівця музичного мистецтва (сольне виконавство, диригування, робота над музичними творами, читання з листа, акомпанування, гра в ансамблі, творче музикування та імпровізація) повинні базуватися на синтезі виконавських і педагогічних якостей, розвинутому естетичному смаку, свідомому ставленні до музичного мистецтва.

У науковому дослідженні “Теоретикометодологічні засади професійної підготовки майбутніх учителів музичного мистецтва до вокально-педагогічної діяльності” Н. Овчаренко теоретично обгрунтовує концепцію соціальної значущості діяльності вчителя музичного мистецтва у формуванні духовної культури учнів, потребу у вчителях, здатних до здійснення вокально-педагогічної діяльності з урахуванням вимог сучасного суспільства. Дослідниця виявляє особливості розвитку і становлення сучасної вітчизняної та зарубіжної музично-педагогічної освіти, педагогічні принципи, особливості оновлювання структури й змісту професійної та мистецької освіти студентів на засадах сучасних педагогічних й психологічних досягнень [4].

Питання формування професійної готовності майбутніх учителів музики у педагогічних коледжах до художньо-творчої діяльності розглядає дослідниця О. Гаврилюк. У ході дослідження вона визначила, що розроблена методика цілеспрямованого формування професійної готовності майбутніх учителів музики до художньо-творчої діяльності здатна позитивно впливати на процес формування професійної готовності майбутніх учителів музики та залежить від усвідомлення власної творчої роботи для виховання школярів [1].

Сучасний науковець О. Хлєбнікова у своїй праці додає необхідність враховувати виховну роль музичного мистецтва у цілеспрямованому формуванні художнього смаку та естетичної оцінки на високохудожніх творах [5]. Тому звернення до музичного мистецтва, як могутнього засобу формування духовності можна розглядати соціальним замовленням, яке стає потребою сучасного життя. На цьому шляху незмірно зростає професійна майстерність учителя музичного мистецтва, 3 моменту виникнення педагогічної професії за вчителем закріпилася передусім виховна функція, а також його діяльність спрямована на передачу підростаючим поколінням накопиченого людством досвіду, сконцентрованого у творах мистецтва, художньо-естетичних цінностей, які 
властиві національній та світовій художній культурі [6].

Загальновідомо, що взаємозв'язок музичного мистецтва та цінностей детермінуються їх спільністю у способах освоєння світу. Вони характеризуються універсальним і ціннісним підходами до людини і світу, є такими духовнопрактичними утвореннями, які функціонують в усіх суспільно-економічних формаціях. Основним завданням професійної майстерності майбутніх фахівців музичного мистецтва $є$ розвиток формування духовних цінностей через ознайомлення $з$ музичним мистецтвом. Тому виховний вплив музичного мистецтва на учня полягає у тому, що, навчаючись розуміти музичну мову, пізнаючи життя за допомогою художніх образів, він осмислює явища дійсності, глибоко переживає їх.

Важливим моментом творчого вдосконалення професійної майстерності майбутніх фахівців музичного мистецтва виступає активізація художньо-аналітичної діяльності студентів, яка стимулює їх творчі можливості, та особистісні творчі якості, розвиваючи художнє мислення, розширяючи обсяг художніх знань та сформованість художньо-аналітичних умінь. Музичні і художні знання не тільки ефективні у процесі мисленнсвої операції-вони формують ці операції, визначаючи структуру та внутрішній зміст. У зв’язку з цим, підкреслюємо, що формування відповідних уявлень та понять має проходити одночасно і на основі практичної діяльності суб'єктів музичного навчання й виховання.

Педагогіка мистецтва підкреслює важливість організації навчання майбутніх фахівців музичного мистецтва в умовах атмосфери емоційного напруження і зацікавленості у сприйнятті та осмисленні музики, тому значна увага приділяється формуванню активного художнього сприйняття музики, вмінь слухати іiі, розуміти й оцінювати. Науковець Т. Люріна зазначає, що гармонійне поєднання художнього сприйняття і художньої діяльності в художньо-аналітичних уміннях допомагає впливати на розвиток художньої культури особистості, урізноманітнити та розширити асоціативний фонд художньоестетичного досвіду, зрозуміти специфічність як кожного окремого, так і синтезу, комплексного та інтеграційного поєднання видів мистецтва [3].

Отже, до змісту професійної майстерності майбутніх фахівців музичного мистецтва можемо віднести придбання необхідних знань, вмінь, навичок, духовних цінностей на основі засвоєння музичної педагогіки зокрема, втіленої у зразках музичного мистецтва, а також використання у педагогічної діяльності нових форм, методів і засобів.

Ми вважаємо, що результативність професійної майстерності майбутніх фахівців музичного мистецтва вимагає виконання певних завдань, а саме:

1. Сприяти формуванню знань, вмінь, навичок, які забезпечують можливість реалізації професійної музичної освіти;

2. Володіння інструментом майбутніх учителів музичного мистецтва в умовах загальноосвітньої школи;

3. Створення комфортного навчального середовища для професійної роботи майбутнього фахівця музичного мистецтва.

Ефективна реалізація визначених завдань у галузі музичного мистецтва повинна виконуватися системою теоретичних знань, практичних вмінь та навичок, через розвиток їхніх інтелектуальних здібностей.

Зазначимо, що перспективи формування професійної майстерності майбутніх фахівців музичного мистецтва в сучасних умовах вимагає оновлення навчально-методичного процесу. Відомо, що майбутній фахівець музичного мистецтва повинен володіти системою теоретичних знань, а саме знати: стиль композитора, зміст та структуру музичного твору, особливості гармонії та фактури, визначення музичного стилю, жанру, формо-структури, елементів художньої виразності. Науковці стверджують: то глибшими будуть знання про твір, то більше вони збагатять уяву і мислення музиканта, поглиблять його розуміння мистецького твору, сприятимуть створенню художньо-переконливої та яскравої інтерпретації музики.

Особливу роль з означеного питання відіграє викладання спеціальних предметів цього циклу: музичного інструменту, музично-теоретичних дисциплін. Це дає можливість значно підвищити рівень індивідуальних форм процесу навчання не тільки з профільних дисциплін, але й практичної роботи. Адже сучасний організаційний навчальний процес посилюється у зв'язку зі зростанням позааудиторної, самостійної роботи у професійній підготовці майбутніх учителів музичного мистецтва.

Наголошуємо на тому, що питання професійної майстерності майбутніх фахівців музичного мистецтва передбачає досягнення більшої досконалості за умов поглиблення знань, вмінь та навичок і творчого використання наукових доробок та досвіду видатних представників 
музичного мистецтва. Такий підхід відкриває нові можливості для поглибленого та якісного навчального процесу. У зв'язку з цим, виділяємо принцип системності і послідовності, на основі якого професійну майстерність майбутнього фахівця музичного мистецтва складає: готовність до оволодіння різноманітними навичками та вміннями, здатності до інтегрування сучасних знань і національних традицій, регіональних напрямів і шкіл.

Висновки і перспективи подальших наукових розвідок. Визначаючи професійну майстерність майбутнього фахівця музичного мистецтва, доречно констатувати, що придбання знань, умінь, навичок у галузі музики є важливою складовою професійної компетентності майбутніх учителів музичного мистецтва. Конкретизовано, що рівень професійної майстерності майбутнього фахівця музичного мистецтва становить важливу умову подальшого розвитку і вдосконалення вітчизняної педагогіки. Знання, вміння і навички, закладені впродовж навчально-виховного процесу в студентів, позначаться на результатах підготовки майбутніх професійних кадрів, реалізації їх як особистостей новітньої парадигми освіти.

\section{ЛITЕРАТУРА}

1. Гаврилюк О. А. Формування професійної готовності майбутніх учителів музики у педагогічних коледжах до художньо-творчої діяльності: дис. ... канд. пед. наук : 13.00.04. Вінниця, 2019. 294 с.

2. Жигінас Т. В. Методичні засади підготовки майбутніх учителів музики до концертно-освітньої діяльності серед дітей та юнацтва: автореф. дис.... канд. пед. наук: 13.00.02, Київ: НПУ ім. М. П. Драгоманова, 2007. 18 с.

3. Люріна Т.І. Підготовка конкурентоспроможних фахівців у вищому педагогічному навчальному закладі. Гуманітарний вісник ДВНЗ “ПереяславХмельницький державний педагогічний університет імені Григорія Сковороди”: зб. наук. праць. Переяслав-Хмельницький, 2015. Вип. 24, C.198-203.

4. Овчаренко Н. А. Теоретико-методологічні засади професійної підготовки майбутніх учителів музичного мистецтва до вокально-педагогічної діяльності : автореф. дис. ... доктора пед. наук : 13.00.04, Кривий Ріг, 2016. 38 с.

5. Хлєбнікова О.В. Формування досвіду музично-виконавської діяльності у студентів вузів культури: автореф. дис. на здобуття наук. ступеня канд. пед. наук: 13.00.02, Київ, 2001. 20с.

6. Щолокова О.П. Система професійної підготовки студентів педагогічних вузів до художньо-естетичної освіти школярів: автореф. дис. на здобуття наук. ступеня д-ра пед. наук: 13.00.01; 13.00.04, Київ, 1996. 43 с.

\section{REFERENCES}

1. Gavryliuk, O.A. (2019). Formuvannya profesiynoyi hotovnosti maybutnikh uchyteliv muzyky u pedahohichnykh koledzhakh do khudozhnotvorchoyi diyalnosti [Formation of professional readiness of future music teachers in pedagogical colleges for artistic and creative activity]. Candidate's thesis. Vinnytsia, 294 p. [in Ukrainian].

2. Zhiginas, T.V. (2007). Metodychni zasady pidhotovky maybutnikh uchyteliv muzyky do kontsertno-osvitnoyi diyalnosti sered ditey ta yunatstva [Methodical principles of preparation of future music teachers for concert-educational activity among children and youth]. Extended abstract of candidate's thesis. Kyiv, 18 p. [in Ukrainian].

3.Lurina, T.I.(2015).Pidhotovkakonkurentospromozhnykh fakhivtsiv uvyshchomu pedahohichnomu navchalnomu zakladi [Training of competitive specialists in a higher pedagogical educational institution]. Humanitarian Bulletin of Pereyaslav-Khmelnytsky State Pedagogical University named after Hryhoriy Skovoroda. Pereyaslav-Khmelnytsky, Issue. 24, pp.198-203. [in Ukrainian].

4. Ovcharenko, N.A. (2016). Teoretykometodolohichni zasady profesiynoyi pidhotovky maybutnikh uchyteliv muzychnoho mystetstva do vokalno-pedahohichnoyi diyalnosti [Theoretical and methodological principles of professional training of future teachers of music to vocal and pedagogical activities]. Extended abstract of Doctor's thesis. Kryvyi Rih, 38 p. [in Ukrainian].

5. Khlebnikova, O.V. (2001). Formuvannya dosvidu muzychno-vykonavskoyi diyalnosti u studentiv vuziv kultury [Formation of experience of musical-performing activity at students of high schools of culture]. Extended abstract of candidate's thesis. Kyiv, 20p. [in Ukrainian].

6. Shcholokova, O. P. (1996). Systema profesiynoyi pidhotovky studentiv pedahohichnykh vuziv do khudozhno-estetychnoyi osvity shkolyariv [The system of professional training of students of pedagogical universities for artistic and aesthetic education of schoolchildren]. Extended abstract of Doctor's thesis. Kyiv, 43 p. [in Ukrainian].

Стаття надійшла до редакції 04.11.2020

\section{G58080}

